\title{
THE QUEST FOR AID COMPLEMENTARITY: REForming COOPERATION BETWEEN NORDIC+ DONORS AND NGOS.
}

\begin{abstract}
Aid fragmentation is a maddening problem in the aid business. NGOs are part and parcel of this fragmentation problem, hence calls for more complementarity between NGOs and (their) governments led to co-funding reforms. We analyse the co-funding reforms of the Nordic+donors and conclude that these donors have interpreted complementarity in very different even contradictory ways. Where some require NGOs to develop activities within the confines of the official bilateral strategy (intensive complementarity), others allow NGOs to do very different things (extensive | complementarity). What all reforms share however is that NGOs are now kept on a shorter leash:funding has become more competitive, tied in with resultsbased agreements and a requirement to intensify coordination and cooperation in bilateral partnercountries.
\end{abstract}

\section{INTRODUCTION}

The perennial lamentation since the inception of the aid business has been fragmentation: too many donors carrying relatively small amounts of money to too many different interventions in too many different countries(Easterly and Pfutze 2008: 2; Acharya et al.2006; Frot and Santiso 2010, 201). Such fragmentation produces high burdens on the recipient and is even considered to undermine institutional performance ((Djankov et al.2009; Knack and Rahman 2007). NGOs are part and parcel of the fragmentation problem, be only due to their sheer number: around $40000 \mathrm{NGOs}$ are internationally active (UNDP 2000).

Better coordination would reduce fragmentation (OECD 2005; Easterly 2007) and since the Paris Declaration (PD) of 2005, the international donor community has recognized donor coordination and increased specialization as tools to combat fragmentation. Such coordination should also encompass an intensified cooperation between civil society organizations and governments (OECD 2005, 2008). Some donors have subsequently reformed their NGO-co-funding system so as to incentivize more complementarity between the bilateral and NGOs development cooperation strategies into more complementarity.

The main question this article sets out to answer -is how these donors have conceptualized and operationalized complementarity. This question is relevant because different, even opposing views on complementarity exist. On the one hand there is this vision that complementarity means that NGO activities should be brought in line with official donor policies. This 'intensive complementarity' (Koch 2007) has been strongly rejected by NGOs themselves because it would jeopardize their autonomy and right of initiative. They argue that NGOs have a different role to play in aid and development, and that their added value lies precisely in doing different things from what official donors do (Fowler 2011: 51). This is what is referred to by Koch (2007) as 'extensive complementarity'.- 
This paper looks at the seven Nordic+ donors (UK, Ireland, Denmark, Sweden, Norway, the Netherlands, Finland) in the period 2000-2010, in order to grasp the ways in which these donors have tackled complementarity concerns in their dealings with NGOs. We focus on how the NGO co-funding systems have pushed the idea of complementarity, and whether these different donors have done this in a similar or dissimilar manner.

Why the Nordic+ donors? These countries entrust a substantial proportion of their ODA to NGOs both in absolute terms and relative to the DAC average (see table below).They were also known to be particularly committed to the PD heralding amongst others the principles of harmonization, alignment and recipient ownership. This group of donors, often also referred to as the 'like-minded donors', have been quite progressive in implementing the Paris Declaration, and their reform efforts may thus signal where other donors could move to to promote greater complementarity between bilateral donors and NGOs. The research is of exploratory nature and our emphasis is on structural, long-term financial support.

Table (i): Bilateral aid (\%) channelled to and through NGOs, 2009 (extracted from OECD 2011a)

\begin{tabular}{|l|r|r|r|}
\hline DAC Member & To & \multicolumn{1}{|l|}{ Through } & \multicolumn{1}{l|}{ Total } \\
\hline Denmark & 3 & 8 & 11 \\
\hline Finland & 0 & 22 & 22 \\
\hline Ireland & 15 & 22 & 37 \\
\hline Netherlands & 21 & 9 & 30 \\
\hline Norway & 0 & 27 & 27 \\
\hline Sweden & 5 & 21 & 26 \\
\hline UK & 4 & 10 & 14 \\
\hline sample average & 6,86 & 17 & 23,86 \\
\hline DAC average & 3,79 & 12,86 & 16,7 \\
\hline
\end{tabular}

The distinction between the two existing accounting categories of aid "to" and "through" NGOs respectively is not clear-cut. While the former implies that donors permit a high degree of autonomy on the part of NGOs (as in when granting core funding) and the latter suggests considerable steering by the back donor (as in when subcontracting/ earmarking funding for specific projects or programmes) in reality these categories represent two poles along a more complex spectrum of arrangements. The consistent application of these definitions by donors in their reporting also leaves much to be desired: Norway for example classes all aid going to NGOs as "aid through" (OECD 2011: 56-7), yet in its major policy document on civil society describes its commitment to provide funding "as multi-year, core support" (Norad 2009: 8). The representation of NGO funding in the table is also probably an under-estimation of what NGOs get from their governments. Additional financing mechanisms are often scattered over different departments and budget lines, and are thus not identified as NGO funding in DAC statistics. Problematic areas include subcontracting, humanitarian aid, special thematic funds, and also the direct funding of Southern NGOs. Matters are set to improve in relation to the final item, given that in 2010 the DAC agreed to augment the current, arguably less than watertight, "aid to" and "aid through" NGO funding typology with a third category viz. 'aid allocated directly to developing country-based NGOs' (OECD 2011: 19). This will hopefully streamline future comparative work in this area and bring donors in line with their PD commitment to enhance Mutual Accountability by "[p]rovid[ing] timely, transparent and comprehensive information on aid flows" (OECD 2005: 8). 
The main conclusion emerging from this research is that our seven donors have reformed their NGOcofunding systems to increase complementarity, but they have done so in very different even contradictory ways.

This paper commences with a brief review of the relevant literature relating to (1)recent trends in shifts of what civil society and NGOs are expected to do and how this relates to fragmentation, and, (2) the debate on the operationalisation of complementarity. From this overview we will draw up a list of features in order to screen the NGO-co-funding reform policy documents. After providing further details of our findings and how these were arrived at, we briefly conclude. This research was mainly a desk-study, carried out in the period 2009-2013, covering the period 2000-2010.We mainly look at the funding modalities which have a clear transfer link to developing countries, we have thus not taken on board those modalities that fund NGOs to do awareness raising in the donor country itself, focus on humanitarian aid, or on direct funding of $\mathrm{CSO}$ s in recipient countries. This study looks into the policy documents, the set-up, not into the actual implementation because we are interested in the conceptualization of complementarity and how donors this translate into funding incentives.

\section{IN SEARCH OF COMPLEMENTARITY: A LITERATURE REVIEW}

\subsection{NEW ROLES OF CIVIL SOCIETY}

Traditionally NGOs have been considered as the cheaper, more effective and efficient service deliverers to the poor. Particularly during the 80s, when downsizing the state and giving more room to the market and private actors was part of the aid agenda, NGOs became the main vehicles for bringing resources directly to the poor. Service delivery projects became the main business for NGOs and they were heavily funded by donors to fill the void the shrinking state had left behind (we need to throw in some references here...).

The good governance agenda which emerged in the 90s however, has marked a profound shift in NGO roles. Civil society organizations are no longer be expected to be mainly deliverers of resources and services direct to beneficiaries because today the state has been brought back into the development equation. The coordination, regulation and/or implementation of service delivery to the citizenry has become againis the main responsibility of the state. Today, a strong civil society is considered crucial in pushing the good governance agenda because it can play a watchdog role, form a counterweight to authoritarian tendencies, push the government towards more transparency, responsiveness, accountability and improved performance ${ }_{2}$-represent the voice from below, articulate demands and interests of the poor and vulnerable (Fowler, 2000). NGOs thus have a crucial role to play in strengthening civil society in the south, not to deliver services, but to take up a much more political role. Cornwall \& Gaventa (2000), argue that NGOs need to move their focus of attention from micro to macro, from projects to policies and from beneficiaries to citizens.

These new roles however also require a shift in funding modalities. The aid effectiveness debate has shown that projects and thus project funding tend to undermine existing structures, produce an overload of transaction costs, are not sustainable and often are too short term to have long term institutional impacts that go beyond the scope of the project. Added to this, projects tend to poach staff and lead to budget burdening which actually undermines institutional development. The 'institutional' turn in donor thinking emphasizes the use of flexible funding modalities which by preference represent long term commitments and predictable funding. In government to government relations this led to a preference for the budget support modality, whereas in civil society funding the use of 
core-funding might be expected to have become a more fashionable way of supporting institutional development at the level of civil society. In other words, flexible, core funding is considered the aid modality most apt to support institutional and organizational development (such as the strengthening of civil society), whereas the funding of parallel projects may go at the expense of institutional strengthening (Assessing Aid 1998; Birdsall 2007).

All the above shifts can have some immediate fragmentation reducing effects because it would prevent thousands of NGOs providing uncoordinated, fragmented services through projects. The withdrawal of NGOs out of service delivery implies that they become more active in policy influencing, monitoring and evaluation, lobbying and advocacy and playing a watchdog role. This is not to say that organizations should completely drop service delivery, but it is ideally a (temporary) role for non-state actors limited to those cases where state structures are totally missing (like fragile states), or for piloting innovative approaches to service delivery, which if well coordinated can afterwards be scaledup by state actors (Riddell, 2007). This is also not to say that all services should be delivered by the state, but the state should play a regulating and/or coordinating role.

\subsection{COMPLEMENTARITY}

In this section we highlight the different ways in which complementarity can be understood, so as to be able to assess the Nordic+ donors in terms of which operationalization of complementarity they handle.

Complementarity can be thought of at the geographical level or at the thematic or sector level, and related to this two main permutations of complementarity can be distinguished (Koch 2007): (1) intensive complementarity which refers to situations where NGOs and bilateral aid agencies work in the same countries and sectors, closely interact and divide tasks according to their respective added value (2) extensive complementarity which refers to situations where bilateral aid agencies and NGOs complement each other by working in different countries and/or sectors, whereby the division of tasks is again based on comparative advantage. The latter scenario is a strategy which for DAC members as a whole is regarded as subsidiary to the goals of supporting NGOs to diversify aid delivery by innovating and piloting initiatives (OECD 2011a: 16).

Koch argues however, that inspite of the significant value of diversity and innovation in specific contexts, fragmentation remains a serious constraint on aid effectiveness. NGOs are part and parcel of the fragmentation problem and partly for this reason Koch (2008: 78) argued that they were in dire need of their own 'Paris Declaration'. The Paris Declaration (2005) did put forward its own solution to fix fragmentation: donor harmonization (or coordination between the official aid agencies) taking the form of exchanging information, harmonizing certain procedures, division of labour, joint programming, joint evaluations, etc... in order to avoid fragmentation, overlap, and the overburdening of the recipient government. Such harmonization however could also be potentially dangerous. It could lead to an unthinking (and counterproductive) type of herd mentality on the part of aid providers (Koch2007). Such herd mentality would trump diversity and per definition also innovation and experimentation.

The above implies that there are two dimensions to complementarity, which are important for our research: 
1) the degree of complementarity : this relates to the concern that there can be too little, but also too much harmonization and,

2) the value: co-ordination valued positively translates into harmonisation, whereas co-operation valued negatively translates into herd mentality.

A similar flipping of the discursive coin might nuance our understanding of the apparently distinct and even opposing terms fragmentation and diversity, which can similarly be respectively understood as the negative and positive valuing of variety (see figure i). Crucially in terms of the key term used in this paper, complementarity can then be understood as springing from these positive understandings of co-ordination and variety.

This implies that when going through the policy documents on co-funding reforms, particular attention should be paid to the degree in which complementarity is incentivized and the justification for it (value).

Figure (i) Values and degrees of complementarity

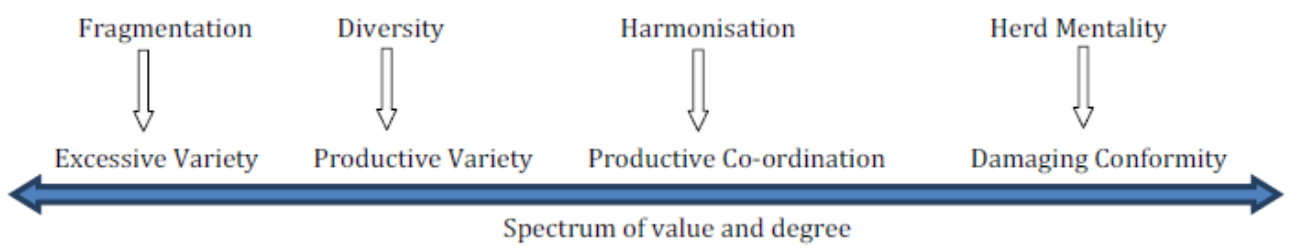

Source: authors

This scheme will be used as a conceptual roadmap in assessing how the different Nordic+donors have interpreted/conceptualized complementarity.

In theory, complementarity seems to be about integrating the best of both worlds, as is illustrated below yet it moves in a continuum where on the one hand complementarity is 'more of the same' versus complementarity as 'less of the same'.

Figure (ii) The quest for complementarity

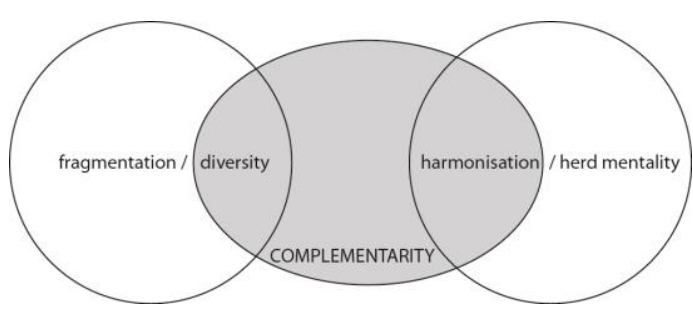

Source: authors

\section{COMPLEMENTARITY AND NGO-CO-FUNDING SYSTEMS IN THE NORDIC+ COUNTRIES}

The insights presented in section 2 provide us with a 'roadmap' to look into the co-funding reforms. To start with we look for references indicating the importance of strengthening of civil society in the 
south. We screen also for the ideas that policy influencing, lobbying and advocacy are preferred NGO roles while moving away from service delivery projects unless specific circumstances (fragile states, demand for innovation) call for it. We must also pay attention to the funding scheme: is there a preference for more long-term funding and core funding? We must furthermore look into the guidelines donors have formulated for NGOs to get access to funding, and whether these incentivize intensive or extensive complementarity. Finally we should pay close attention to which funding modalities are used by the donors to incentivize complementarity.

Annex 1 gives a more detailed overview of the different reforms in the Nordic+ countries in terms of funding modalities and criteria used to grant access to NGOs. Below a brief summary per country is given.

\section{THE UK}

In 2006, the UK launched its NGO strategy entitled "Civil Society and Development: How DFID works in partnership with civil society to deliver the MDGs". In 2009 "a new approach to civil society" was announced in the White Paper "Eliminating World Poverty: building our common Future".

DFID's policy aims 'to build voice and accountability', 'to provide services' (especially in fragile states and in search of innovation) and it sees civil society as playing "an important and complementary role to government and the private sector in poverty reduction (DFID 2006:6).

In terms of funding modalities, the Partnership Programme Arrangements (PPAs) are strategic level cooperation agreements between DFID and large NGOs that specify jointly agreed outcomes and provide strategic funding over 3-6 year timeframes. Funding is thus based on shared objectives. Initially the recruitment process for this funding was not very open, but since 2002 it became increasingly competitive. Both UK based and foreign NGOs can apply for funding.

At the same time, DFID also continued to fund small and medium-sized UK based NGOs through the Civil Society Challenge Fund (launched in 2002). Since 2004 it funds interventions that encompass service delivery in difficult environments and projects that develop innovative methods to service delivery. The fund specifically wants to support smaller organisations, increase development support in the UK and foster innovative approaches (DFID 2006).

The Governance and Transparency Fund (DFID 2007) funds large scale programmes targeting these two areas. Access is very competitive and non-UK organizations can apply for funding. Submitted proposals do not have to be carried out in UK partner countries, but given the topical emphasis of the fund, it is defacto a way of streamlining a topical approach into NGO activities.

The thematic guidelines very much emphasize the importance of supporting the MDGs, addressing security issues in fragile states, gender and climate change. The geographical guidelines distinguish between partner countries and the rest. PPAs in partnercountries should relate to the DFID strategy. Activities in non-partner countries is allowed but priority must be given to poorest countries.

In supporting NGOs, two major issues stand out: the UK mainly sees NGO support as instrumental for the realization of poverty reduction goals_(particularly the MDGs, and particularly those that are most off-track in a given partner country) and it aims at integrating civil society into its governance agenda. Funding for service delivery still exists but it is more short term and for smaller organizations (Udsholt 2008). Furthermore, complementarity is interpreted differently for different types of interventions: the larger programmes with more flexible funding require the formulation of joint outcomes, whereas smaller grants leave somewhat more room for diversity in approaches. 


\section{IRELAND}

Ireland reformed its co-funding policy in 2008. The "Civil Society Policy" not only clearly refers to the Paris Declaration as a major motivation for re-organizing the funding of NGOs, it also explicitly mentions the broader civil society goals it wants to achieve, namely to 'support an enabling environment for civil society', 'support the role of civil society in promoting participation and good governance', and 'support the role of civil society to build a constituency for development, human rights and social justice' (Irish Aid 2008b:13). The Policy also mentions that it wants to 'support the role of civil society in pro-poor service delivery and growth' but that the creation of parallel structures should be avoided. Organisations are expected to work with the state and align with existing policies in recipient countries (Irish Aid 2008b:13).

In terms of funding modalities the 2008 policy continued the Multi-Annual Programme Schemes (MAPS) system which entails a long-term (5 year timeframe) predictable programmatic approach to funding. MAPS started in 2003 but were updated in 2008. To get access to MAPS, organisations must have sufficient organizational capacity, have a strong relationship with Irish Aid, and may furthermore not be dependent on official funding for more than 70\% of their total funding (Irish Aid 2006a).

Organisations covered by the MAPS need not be consistent with Irish Aid thematic or country foci, but they do need to contribute to the overall very broad objective of poverty reduction, strengthening of civil society and improving governance. Internal coherence at the level of the individual NGO strategy is expected though: an NGO programme should mainstream its own priorities throughout their programme. In Irish Aid partner countries, a close coordination between MAPS organisations and Irish Aid is expected. This includes regular consultations between those involved in bilateral and MAPS aid programmes, and identification of opportunities for institutional cooperation. Irish Aid considers cooperation between MAPS organizations a very important and unique mechanism for mutual exchange and learning (partner fora, joint research, joint initiatives).

The Civil Society Fund (CSF) is a tiered fund that finances the activities of organisations of various sizes and capacities. CSF puts following topics forward: strengthening voice and participation of civil society, improving services, supporting human rights and responses to HIV/AIDS. CSF grants are additionally encouraged to focus on topics of climate change adaptation, agricultural research and nutrition. NGOs who apply must therefore explain how their planned activities contribute to these goals. Proposals that focus solely on service delivery will not be financed. Interestingly, the CSF grants both project and multi-annual block grants. Access to the latter require an organizational assessment and the ability to have a programmatic approach. Applicants must also prove that they cooperate and coordinate with local and national governments as well as other NGOs. Although coherence with the Irish government policy is desirable it is not a requirement.

Since 2006 the Micro-Projects scheme (MPS) funds projects for small NGOs. These projects however are not allowed to focus solely on service delivery and need to be in predefined sectors (which are by and large quite widely defined and include topics such as democratic governance), and consistent with government policy and Irish Aid policy (Irish Aid 2006b).

In terms of geographical guidelines, priority is given to Sub Saharan Africa because that is where the focus of Irish Aid is. As a result, organisations working there are given priority.

In general Irish aid has moved towards granting more professional organisations more strategic programme funding. Coordination between Irish Aid and these organisations is deemed important, but both intensive and extensive forms of complementarity are possible. Interestingly, Irish Aid puts significant emphasis on NGO-to-NGO coordination, particularly between the larger organisations, and 
on coordination in the field with government and/or NGOs. Smaller, project-oriented organisations are required to focus on Irish Aid priorities to a greater extent, which is a seemingly opposite strategy than UK where smaller project organizations get more leeway and less restrictions.

\section{DENMARK}

Denmark's reform of its co-funding system in 2000 and in 2008 was entitled 'Strategy for Danish Support to Civil Society in Developing countries' (2000, Dec 2008) ${ }^{1}$. We focus on the 2008 strategy which was partially designed to bring the policy in line with the Paris Declaration and where specific reference is made to the need for CSOs to promote ownership and to harmonise, but only if this does not in any way threaten their diversity (General Principles 2011:1-2).

According to the official policy, NGOs should place particular emphasis on capacity development of civil society so as to increase the involvement in advocacy work locally nationally; regionally and internationally and that the capacity to develop and participate in national, regional and international networks is supported (Danida 2008:5). Danida has not moved away from projects and service delivery in its co-funding requirements, but parallel structures, duplication and substitution are to be avoided. Parallel projects are only accepted if they entail the testing of an innovative approach or the inclusion of excluded groups.

Historically DANIDA and Danish NGOs have had a very close relationship and shared a consensual view on Danish Development Cooperation. While representatives from NGO FORUM do not meet with the minister of development cooperation as frequently as its predecessor umbrella organisation (the Kontaktudvalg, or NGO Contact Committee), the dialogue they have with the ministry tends to be productive, as is also evidenced by the fact that the CSO strategy was prepared jointly with Danish CSOs (DAC peer review 2011:47-48). The most important NGOs have a seat on the Danida Board and NGOs appoint representatives to the Danida Council for International Development Cooperation. NGOs are consulted by Danida on sector and country strategies. This institutional intertwining between some NGOs and the government, which seems to point to strong coordination efforts and thus strong complementarity, has however led to the perception that these organisations have become 'extensions' of the government and that innovation, critical distance,societal embeddedness and legitimacy were lacking (DAC 2003a). This perception was exarcerbated by the fact that Danish NGOs were also heavily dependent on government funding.

These issues have led to a shift in funding requirements with a particular emphasis on strengthening NGOs' autonomy, accountability to their members and financial independence. Important to mention is that Denmark has been working with Framework agreements since 1991, although this funding modality in subsequent reforms has undergone some substantial changes:

- from fully funded to more self-funding. Danida introduced a self-financing requirement of 5\% in 2006 (Danida 2006)and from 2007 onwards this increased to 10\%.This shift has particularly affected the larger organisations which had to start looking for additional sources of funding to finance their programmes.

1 General Principles governing support to development activities implemented by Danish Civil Society Organisations (published January 2011) summarises this document and explains how it fits in in terms of other domestic and international agreements and conventions governing the provision of development assistance. More technical guidelines include General Guidelines for Grant Administration through Danish Civil Society Organisations (August 2010) and the older but still current Guidelines for the administration of the grant scheme for small projects allocated by the Danish Ministry of Foreign Affairs (October 2006) 
- from cosy to competitive: Framework NGOs have since 2000 been subject to increased standards relating to results-orientedness, but also societal embeddedness and legitimacy in Denmark (Randel\& German 1999c). Organisations must, for example, give information on membership numbers and information on campaign activities.

- from exclusive to inclusive: a 5\% drop in the budget for Framework agreements in 2004 allowed Danida to redistribute these funds to smaller NGOs (Pratt et al. 2006) which are currently managed through a delegated funding arrangement facilitated by the PATC (Project Advice Training Centre). However, there are plans to increase the number of framework agreements from six to potentially 18 by 2015 by converting current programme agreements to framework agreements, despite significant differences in size and approach of the organisations in receipt of both types of agreements.

In terms of complementarity NGOs were expected to concentrate their activities in a limited number of countries and sectors, but were not requested to follow the bilateral choices in these areas. If however an NGO does work in a country and sector where Danida is active, it needs to coordinate closely with respect to strategy, focus area and approach. In more general terms NGOs are expected to contribute to the transversal, and quite broad goals of gender, environment and/or democracy. More important, however, is that NGOs must have a good knowledge of context, of local development plans or strategies and that their interventions are coherent and relate to those higher goals (with alignment where possible). Furthermore Danida pushes for NGO coordination and for as much exchange as possible. Danish NGOs are required to coordinate with each other, with other INGOs, with donors, and with the Danish Embassy in the field if the NGOs in question work in same sectors as Denmark does. Danish NGOs must also harmonize their administrative prerequisites with their partners' funders and are allowed to pool funding with other actors.

In general, Danida has been tightening the control over NGOs and pushing them towards more results orientation, more coordination and more embeddedness. It is considered important that NGOs take into account the larger picture when planning interventions: such as national development strategies of countries where interventions take place, acknowledging the role of the state and coordinating with relevant actors. Complementarity with higher level objectives is thus important, but need not be necessarily Danida objectives.

\section{SWEDEN}

The policy documents 'Sida's support to civil society in development cooperation' (Sida 2007) and 'Pluralism, Policy for support to civil society in developing countries within Swedish Development Cooperation' (Sida 2009) share the same ideal of wanting to strengthen pluralism/democracy, empower poor people, support a strong and vibrant civil society and promote rights-based approaches in order to advance poverty reduction. They aspire to co-funding arrangements which draw on "welldesigned and flexible contribution systems" and which are guided by the Paris Agenda principles of harmonisation, alignment and local ownership (ibid, p.23).

The 2007 policy refers to the importance of supporting civil society in its role as a watchdog, due to the focus on ownership and alignment and the subsequent shift of attention to recipient governments (Sida 2007). Notwithstanding the importance of voice, SIDA takes the standpoint that service delivery and advocacy can go hand in hand (SIDA 2009).

Historically, much like the Danish case, Swedish NGOs enjoy a close relationship with the official aid agency. Representatives of NGOs have a seat on the SIDA board and many SIDA officials have been active in NGOs (and vice versa). This history of substantive dialogue between both 'sectors' has evolved into a close and consensual relationship which nonetheless safeguards NGO autonomy. 
Interestingly then, despite this institutional interdependence and financial dependence, Swedish NGOs have maintained a strong sense of autonomy (Randel\& German 1999d). This respect for NGO autonomy has however also historically led to very loose management of NGOs by SIDA. According to Riddell et all (1995) SIDA mainly focused on financial reporting rather than on assessing impact.

The 2007 and the 2009 policy tried to address these issues to some extent. The guidelines for the 2007 and the 2009 policy specify that the goals and principles of Swedish development assistance must form the basis of NGO activities and that organisations must document in their proposals and reporting how they contribute to these goals. Also, when NGOs plan activities in bilateral partner country, organisations must show how their activities relate to the bilateral strategy. Organisations working in Sub-Saharan Africa are also required to incorporate a HIV/AIDS perspective into their work.

In terms of funding modalities, Sweden has a long established experience with framework agreements which also provide some core-funding. These framework agreements cover longer periods of time (810years) while funding commitments span 3 to 4 years $^{2}$. At the moment of drafting this paper, 15 organisations receive this type of funding. It is predominantly the larger, more professionalised organisations that have passed an audit which are eligible. Smaller NGOs get access to funding through the framework for umbrella-organisations. Many of the framework organisations function as grantmediators (i.e. funding intermediaries) and in fact this is the only way in which smaller, less established NGOs can access SIDA funding, since SIDA's entire CSO budget line goes to the framework organisations, who then redistribute part of the funding to their members organisations according to the procedures agreed with SIDA.

In general terms, SIDA encourages NGOs to prioritize the Partner countries' priorities but also to work on the very broad topics of democracy and good governance, sustainable development, gender, eduction, health, rural development, environment, climate challenges, youth and discriminated minorities.

In general, the co-funding system in Sweden has put the NGOs on a somewhat shorter leash in that NGOs now must relate to the bilateral strategy in partnercountries and some topical guidelines are introduced for NGOs to get access to funding. Beyond this requirement however Swedish NGOs receive considerable leeway to pick where and how they develop their activities.

\section{NORWAY}

The Principles for Norad's Support to Civil Society in the South (May 2009)clearly refer to the Paris Declaration stating that "dialogue with the organisations will emphasise how the five principles of aid effectiveness, as formulated in the Paris Declaration of 2005, can be implemented and developed in a

| manner consistent with civil society work" (op cit Principles, p. 17). The same document also indicates that Norad prefers NGOs to engage in rights-based work, lobbying and advocacy. Service delivery roles are allowed too, but mainly in conflict affected areas and in general there is not such a sharp distinction made between support for service delivery, capacity building and advocacy work (Norad 2012).

\footnotetext{
${ }^{2}$ More information: http://www.sida.se/English/Partners/Civil-Society-/Funding-support-to-civil-societyorganisations--/Framework-organizations-/ (Published: Tuesday, June 23, 2009, Changed: Tuesday, May 04, 2010) and sourced from this official document dating from 2007: http://www.sida.se/Publications/Import/pdf/sv/Guidelines-for-Grants-from-the-Appropriation-for-NonGovernmental-Organisations 1679.pdf.
}

Field Code Changed

Field Code Changed 
Norway is known for channelling a major share of its ODA through NGOs (MFA 2004). The historically close relationship between NGOs and Norad has, much like in the Denmark case, raised concerns about the autonomy, independence and societal embeddedness of Norwegian NGOs. NGOs seemed to become part of the 'mainstream' development actors in which there are no clearcut differences anymore between 'official approaches' and 'NGO approaches' (MFA 2004; Randel\& German 1999a; Tvedt 2007, Toje 2011). Although this proximity did not necessarily determine where Norwegian NGOs were active, or in which sectors they developed their activities, the intertwining of Norad and Norwegian NGOs did lead to concerns of 'critical distance' and openness for new players.

The 2009 reform introduced some changes to tackled some of the above mentioned challenges: selffunding requirements were imposed, new funding modalities for smaller, newer organisations were developed,.

In terms of funding modalities there are three schemes. The framework agreements ( 80 organisations in 2012, agreement span 3-5 years) are referred to as long-term cooperation and requirements there became stricter (at least on paper) and moved toward intensive complementarity (DAC 2011 p. 19) although this is not mandatory (Karlstedt 2010 p. 1 of Annex 3). Next there are the project agreements (1 to 3 years) for smaller organisations. Finally the small grants administered by and managed by umbrella organisations.

In general, Norwegian NGOs are expected to have knowledge of Norwegian development cooperation policies. They are also expected to improve coordination with donors, but it must not be Norway. In terms of topical guidelines, these are defined very broadly in the sense that if they contribute to sustainable social and economic development they are acceptable. No geographical guidelines exist.

In sum, Norway seems to display some interesting and contradictory features. On the one hand NGOs looked too much like official players in the way they went about in development cooperation, but this did not imply that they were active in the same countries or sectors. On paper the government pushes these larger players toward more intensive complementarity but it seems that in practice this is not really happening since coordination efforts are requested but it should not be Norway.-

\section{THE NETHERLANDS}

The Policy Memorandum of the Netherlands on Civil Society Organisations: Cooperation, Customisation and Added Value (April 2009)states that "the overarching goal of [their current co-financing arrangement] is to contribute to direct poverty alleviation in developing countries by strengthening local CSOs and contributing to the achievement of the MDGs".

The policy document furtheron clarifies that civil society is expected to primarily participate in democracy building, in rights based work, in lobbying and advocacy. Political work is thus encouraged, but service delivery activities (particularly) in fragile states are still allowed.

The Dutch co-funding system has undergone substantial changes in the last decade. Until 2005, five NGOs were legally entitled to receive $10 \%$ of total Dutch ODA through core-funding (Koch Blind Spots $\mathrm{p}$ 42). Since then, the system has become more open and more competitive. Control over organisations' activities has become more pronounced, with a move away from core-funding and into programme funding. The focus on results has come to the foreground and the entitlement of NGOs to a certain portion of ODA has been dropped. Ruben \& Schulpen (2008) have analysed the evolution of 
Dutch co-funding modalities over the last 10 years and they conclude that quality standards with regards to NGO performance and effectiveness have been raised substantially and that the focus on synergy with the official Dutch aid strategy has been significantly strengthened. The Dutch government also expects NGOs to demonstrate their 'added value' and specialize as watchdogs and as actors with the ability to reach marginalised groups (MFA 2008a). NGO interventions should also be tailor-made and context specific. The same authors argue that over the course of the last few years a gradual shift has taken place "from NGDOs considered as outsourcing through semi-autonomous agencies toward a more functional approach of subcontracting NGDOs' whose work complements ongoing bilateral and multilateral initiatives (Ruben \& Schulpen 2008:17).

Complementarity and combatting fragmentation is thus a major focus of the most recent Dutch cofinancing reform and is also one of the reasons the MFA chose to move to a unitary system of subsidy requests, integrating the separate thematic co-funding it had introduced previously for smaller organisations into one overarching co-financing system in which all NGO activities' could be directly compared (IOB 2009: 19). The selectivity criteria used to evaluate applications for funding further illustrate how the complementarity requirement plays out concretely: 15 points (out of a total of 100) are awarded to an organisation or alliance in the final "programme" stage of the application based on their demonstrable ability to harmonise their operations with the work done by other (Dutch and nonDutch) actors in the same country and sector (Staatscourant no. 11736, 2009) in order to mutually strengthen each others' efforts and achieve synergy. Complementarity with Dutch bilateral aid can take different forms, depending on the context of the intervention. It can range from full alignment (e.g. in certain sectors in Dutch bilateral partners countries, to partnership, to coordination or mere exchange of information).

In terms of geographical guidelines, financially, $60 \%$ of the grant amount must be spent in the partner countries of the Netherlands (unless this is deemed inappropriate for a specific call for proposals). NGOs can allocate outside the partner countries, but then LDCs should get preference.

Topical guidelines refer to the four focus areas in Dutch Development Policy: growth and equity, gender equality, rights to sexual and reproductive health, peace and security, environment, energy and sustainability.

A final feature of the revised Dutch co-funding approach which especially stands out is the move away from core funding. The previously high proportion of this kind of funding was internationally unique (Koch and Loman 2008, Ruben and Schulpen 2009).

For the Dutch case the An-evolution is clearly discernible: away from the privileged treatment of select organizations who enjoy extensive autonomy towards more steering, more contractual and more intensive complementarity.

\section{FINLAND}

The DAC peer review in 2007 urged Finland to address its vision on NGO co-funding. According to the DAC the Finnish government lacked strategic vision while Finnish NGOs were accused of being out of touch, due to a lack of knowledge and awareness, with the Paris Declaration and international evolutions with regards to NGO roles and civil society roles in development and aid.

These challenges were addressed by Finland in its Guidelines for Civil Society in Development Policy (November 2010). It was stated that the goals set in the Paris Declaration should serve as an 
important guideline in CSOs development cooperation. The guidelines furthermore state that "the role and importance of civil society actors have become increasingly prominent, especially in the debate on development policy coherence, the fragmentation of assistance, and on the reconciliation of humanitarian aid, reconstruction and development cooperation. The debate has focused, on the one hand, on respecting the free and independent position of civil society actors and, on the other hand, on more effective utilization of their potential as part of the development cooperation as a whole" (op cit p. 18). Finland thus acknowledges the distinct role civil society plays and that their autonomy and right of initiative has to be respected, yet it also points at the need to address fragmentation. Its 2012 Development Policy guidelines ${ }^{3}$ furthermore encourages CSOs to promote effectiveness in accordance with the guidelines of the Istanbul Principles, and also commits to increasing funding through CSOs.

In terms of broad goals it is stated that "from the viewpoint of development cooperation, the essence is that efforts and support to strengthen civil society are aimed at the eradication of poverty and promote economically, socially and ecologically balanced sustainable development, in accordance with the UN Millennium Development Goals set in 2000" (2010 p 6). The policy clarifies that from the perspective of development cooperation civil society has a number of roles and tasks such as: the promotion of human rights, democracy, and good governance, civic education, knowledge of rights, learning about local democracy practices, production of basic and welfare services, monitoring of the State and other public-sector actors (democratic control), defending the rights of minority groups, increasing grassroots participation, promotion of a pluralistic and, multifarious civil dialogue and participation in such civil dialogue, mobilization of local resources (including volunteer activities), testing and development of innovative operational models (2010 p 6). The policy document consistently acknowledges the importance of both service delivery and more political/policy roles but it seems to highlight that greater investment in strengthening civil society in the south is needed:"The most important general task of civil society is to try to empower citizens to influence public decisionmaking processes actively, thereby also influencing their own lives [...] Nearly one-third of the development cooperation funds granted to civil society organizations by the Ministry for Foreign Affairs has supported the provision of basic services, such as education and health care. The organizations have used about one-quarter of the support received for strengthening civil society and for direct support to civil society organizations in developing countries [...] These guidelines do not require radical changes in the structure of activities, nor is it necessary to abandon the provision of basic services. Organizations and other actors, however, are encouraged to assess the weightings of their activities and to consider further investment in the strengthening of civil society in their partner countries."(Guidelines pp. 14-16)

Two main funding modalities exist. The first one is the partnership agreements for larger NGOs which accounts for over half of all aid to $\mathrm{NGOs}^{4}$ (Virtanen et al. 2008).These organizations get invited to the so-called Partnership Forum, which meets once or twice a year in order to have a policy dialogue with the government ${ }^{5}$. It is expected that they coordinate with the MFA in order that their activities

${ }^{3}$ For more information see:

http://formin.finland.fi/public/default.aspx? contentid=251855\&nodeid=15457\&contentlan=2\&culture=en-US

4 For more information see: http://formin.finland.fi/public/default.aspx?nodeid=15436\&contentlan=2\&culture=en-US (updated 10/19/2012). In contradiction the 2012 DAC peer review states "Despite having a variety of funding mechanisms for CSOs, over half of funding goes to a large number of small projects".

${ }^{5}$ Usual caveat applies though "Regular meetings between KEO-33 and the POs (i.e. the Partnership Forum) and among the POs were introduced after the transition to the Partnership Scheme. The new communication fora have improved dialogue and transparency in the Scheme. However, while those PO representatives who participated in the PS preparation process considered it good and collaborative; they were worried about increasing bureaucratisation. Most of the discussions in the Partnership Forum address technical issues while issues of substance are seldom brought up." (Finnish Partnership Agreement Scheme Evaluation report 2008:1 p. 43). 
aregenerally in line with the broad goals of Finnish aid and more specifically that they are harmonized/consistent with Finland in terms of integrating the latter's cross-cutting issues into their thematic foci. Finnish NGOs reliant on this modality must also argue their 'added value'. Alignment with the government of the country of operation and harmonisation with the international donor community is also encouraged (MFA 2012: ${ }^{6}$ ), although it is also stated in the Guidelines that in order to safeguard diversity "Finland does not consider it appropriate to seek to harmonize the selection of beneficiaries, the content of cooperation, or the thematic or geographical priorities" (2010: 19). The second channel funds projects of small and medium sized NGOs. Here, organizations can implement their projects in the sectors of their choice in any of the countries mentioned on the OECD Development Assistance Committee list of eligible countries. The MFA encourages organizations to implement projects especially among the poorest and least developed countries. The 2012 DAC peer review criticised Finland's overreliance on the project modality (through which almost half of all CSO funding is provided) and urged it to move to a more programmatic approach and to provide more core funding, a recommendationwhich it plans to realize through increasing the number of partnership (framework) organizations.

In the Finnish case then geographic and thematic complementarity ${ }^{7}$ (which relate to strengthening mutual support and compatibility with public development policy) is considered desirable but is not strictly enforced. This might be explained by the fact that, as noted in a major evaluation of partnership schemes (MFA 2008), "general compliance with Finnish development policy and the MDGs is actually a non-issue due to the very general character of both the MDGs and the [partnership organisation]s' programmes. The same general goals are also shared by most of the partner countries". Nonetheless, the Guidelines state that the MFA is in the process of developing means to incentivise Finnish organizations to focus their work on the thematic as well as regional and country-level priorities of Finnish development policy (2010 p21). ${ }^{8}$

In sum, Finland seems to be quite different from the other Scandinavian countries due to its higher level of fragmentation in terms of NGOs and their activities. As such this reform mainly tries to push NGOs in considering more broader dynamics and the need to coordinate. In that sense, the steering by the back donor is rather gentle, more in terms of giving signals and incentivizing, rather than turning it into a hard condition.

\section{EMERging Patterns}

\subsection{THE NEW ROLES OF CIVIL SOCIETY}

${ }^{6}$ For more information see: http://formin.finland.fi/public/download.aspx?ID=98446\&GUID=\%7BFE548867B70E-431F-B39A-9D39B8883A4A\%7D

${ }^{7}$ except for the cross-cutting themes, which are compulsory to integrate.

8a major independent evaluation of the partnership schemes that was published in 2008 repeatedly recommended "the Pos to focus their programs both geographically and thematically" but preferably not by moving toward intensive complementarity given the prevalence of Finnish partnership NGOs in non-bilateral partner countries. According to the curent guidelines geographic complementarity may be either extensive or intensive for partnership organisations ("organisations[..] choose their partners, forms of work, countries of operation and beneficiaries based on their own values" - from the - Instructions concerning the Partnership Scheme - incidentally the 2012 update of this document which is currently available on the website is not noticeably different from the draft version published online in 2011 and from which I sourced part of this section). However, thematic complementarity has to be (partly) intensive in that the crosscutting issues have to be integrated (organisations are also evaluated on the manner in which they plan to, or have, integrated these). But organisations receiving project funding are also encouraged to include these themes, so it doesn't seem to me like there is such a clear divide between the two modalities along the in/ex tensive demarcation. 
All seven countries developed an NGO policy or strategy that explicitly refers to the principles of the Paris Declaration. All policy documents highlighted the importance of strengthening civil society in developing countries as an intrinsic goal. Three donors even explicitly referred to this objective in the title of their NGO policy (Denmark, Norway and Sweden).

Some donors in our sample have clear preferences for NGOs to shift away from service delivery and towards promoting advocacy and lobbying (Denmark, Norway, Netherlands, Finland), but none of them exclude service delivery, particularly not in difficult contexts such as fragile states, or where propoor service delivery is lacking, or when linked to innovation, policy influencing or learning. Some donors however explicitly request that NGOs avoid the use of parallel structures. Interestingly, the project funding modality is often considered an entry point for smaller, younger organizations which on the one hand seem to carry the potential for innovation, and on the other also increase legitimacy for development cooperation, ensure societal embeddedness, and introduce variety and diversity into the NGO-landscape. As such, there is thus no courageous or bold shift away from the project modality.

The shift toward core-funding, considered the most apt modality to allow institutional development, was less explicit as expected. The Netherlands even moved away from core-funding, which was a surprising finding. The main approach seems to remain the programme-funding approach (framework-agreements) but what is new is that a number of donors introduced more competition at that level, opening up the playing field. This sometimes includes a shift towards stricter ex ante conditions and in some cases some earmarking: the link with and contribution to MDGs for example, or objectives stated in the bilateral strategy which for the most part are fairly broad.

Interestingly, the policy documents suggest that the reforms want to transform the bilateral donorNGO relationship into a more policy-based partnership. The idea of giving more substance to donorNGO dialogue, i.e. moving from pure financial reporting and accountability to more substantive policy dialogues was a concern for all the donors in our study. Such aspirations however of course do not say much about the actual quality of such dialogues.

Ireland stands out because of its emphasis on NGO-coordination and the importance of coordination in the field, allowing as such for a view on complementarity that is more relating to the field than to bilateral donor strategies. It is striking that the harmonization efforts undertaken in the co-funding systems do maintain a vision on harmonization that is mainly a head quarters vision: national NGOs coordinating with national government in the donor country. This 'input- harmonization' however says little about the subsequent steps in the aid chain and if there are any fragmentation reducing effect on the output-side.

Interestingly, most donors in our study explicitly refer to direct funding as an important instrument to strengthen civil society in the south. Recent evaluations have also shown that public donors are moving towards more core funding in their support to Southern NGOs, usually through pooled funds from different donors (Scanteam 2007).

\subsection{COMPLEMENTARITY}

If we consider the full spectrum of the fragmentation - harmonization conceptualization as discussed in figure (i) and (ii), and add the empirical insights to this, an interesting and diverging picture emerges (see figure (iii)). Note that this figure does not want to place/rank all the different donors, nor does it want to give a full overview of all the funding modalities/donor. Its aim is to contribute to the conceptualization and operationalisation of complementarity in showing the diversity found. 
Figure (iii): Quest for complementarity summarized

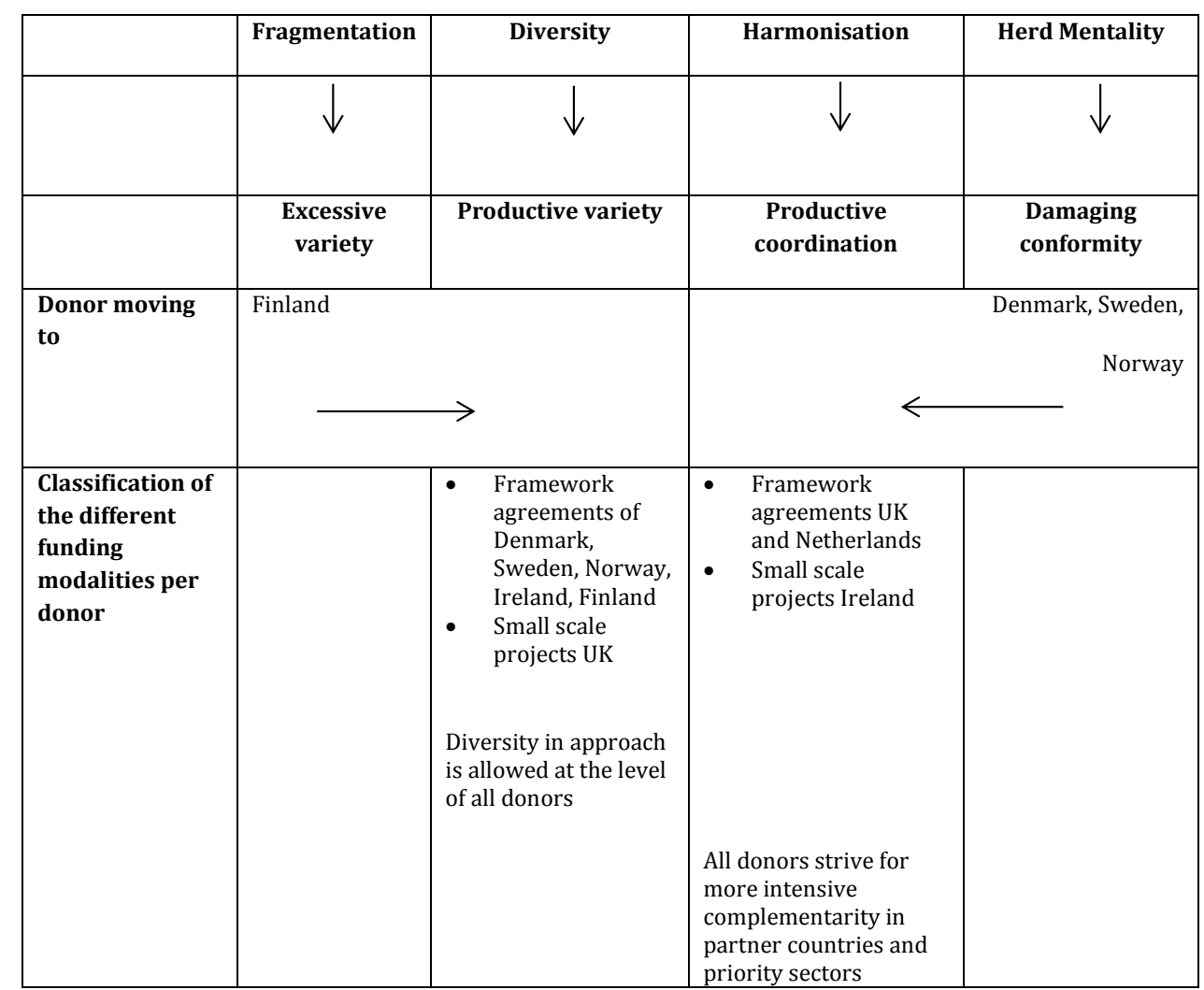

Source: Authors

The table above visualises the continuum between fragmentation (which is considered excessive variety) and herd mentality (as damaging conformity).

To start with, it is clear that all donors envisage more complementarity. What differs however is their starting point, and the extent to which they prefer intensive of extensive complementarity.

On the right hand side, we placed the donors who found their relationship with NGOs to be too cosy. The close intertwining between official and NGO-positions, sharing the same vision on development cooperation seemed to lead to a perception of damaging conformity, even if the different actors were active in different countries/sectors, and even if the autonomy and right of initiative of the NGOs was not necessarily under threat. The arrow indicates that these donors (Denmark, Sweden and Norway) clearly reformed the system toward more diversity as they explicitely opened up the playing field for more actors. Donors also encourage NGOs to coordinate with other actors (other NGOs, local governments in the field, relevant stakeholders). This diversity in coordination approaches is thus allowed, but not all donors provide funding for this, with the notable exception of Ireland.

On the left, we placed Finland because-it started the search for more complementarity from a different starting point, one where a lot of project fragmentation and too much diversity called for a restructuring toward more productive forms of variety.

The middle columns, which are both different expressions of complementarity, also show how different donors have organized their incentive system for NGOs. Harmonisation which is supposed to 
lead to productive forms of coordination, was interpreted very differently by donors: from very broad (international) goals (such as the MDGs) and leaving a lot of room for extensive forms of complementarity and thus substantial variety in practice, to more narrow and stricter compliance with the bilateral strategy (exemplified by the UK and the Netherlands).

In searching for more complementarity some donors have attached stricter criteria to the framework agreements in order to encentivise a closer relationship between the larger, more professional NGOs and the bilateral strategy. Other donors have focused on bringing projects and smaller NGOs in line with bilateral policies. And yet another strategy (Netherlands and Finland) relies on the bilateral donor coordinating closely with the larger NGOs through framework agreements, while delegating In terms of modalities thus, donors have chosen very different strategies.

Interestingly, Scandinavian countries are all in favour of extensive complementarity when framework agreements are concerned. The UK however expects from framework agreement NGOs to step into the bilateral strategy and strive toward intensive complementarity. In that sense there is a convergence in the Nordic+ donor group: they all want complementarity, but there are also important differences, particularly relating to the framework NGOs versus the smaller or project NGOs.

Another point of convergence is that it seems that intensive coordination is gaining popularity particularly when NGOs are active in partner countries_or in priority sectors. And since research has shown that NGOs and bilateral agencies tend to share the same geographical preferences [Koch (2009) and Nunnenkamp et al (2008)], this search for geographical forms of intense complementarity seems a logical step. When extensive geographical complementarity is explicitly encouraged it is usually mentioned in relation to targeting the poorest countries (Finland).

All donors make extensive use of thematic guidelines. This seems to be a popular way to steer the cofunded activities of the NGOs to a larger extent and connect them to official development policy objectives. Thematic funding can be integrated into the general funding modalities by e.g. specifying that smaller organisations can only request funding in order to do work on specified themes (as was the case in eg. the Netherlands and Ireland); by launching special funding rounds for proposals that relate to certain themes the aid agency has prioritised, eg HIV/AIDS or governance (Denmark/UK); or by requiring project proposals to integrate bilateral cross-cutting themes (eg. Sweden which requires the integration of a rights-based approach to poverty reduction or Finland which is very explicit about this requirement).

\section{CONCLUSION}

The translation and operationalization of complementarity differs widely between the Nordic+ donors. Some mainly want to bring the frame work NGOs in line with the bilateral strategy, some mainly the project NGOs. For some harmonization means walking in line with the bilateral strategy (intensive complementarity), while others validate the distinctiveness/diversity of NGOs in that they do different things and to things differently, although some complementarity with some, fairly broad objectives (international, local, partners) must be present (extensive complementarity).

All in all however, the co-funding reforms have introduced more competition for access to flexible and long term funding. A financial contribution from the NGO itself is also often required as an indication of societal embeddedness. And although results-based references abound in the different reforms, it still grants NGOs considerable flexibility in implementation. Project funding, thematic funding, and a 
host of funding modalities are also deployed by donors to incentivize NGOs to seek complementarity with goals beyond the scope of their particular interventions.

One last element is that most of the co-funding reforms in their search for complementarity heavily focussed on complementarity on the input-side of the aid chain: bringing programmes and/or projects in line with broader goals (bilateral or international). Yet they ignored the question if is complementarity as envisaged has any fragmentation reducing effects in the field. Added to this, it remains a question how these reforms have landed in reality. Are practices close to the policies on paper? Or are substantial gaps present? Are NGOs and donors in partner countries effectively coordinating? Are policy dialogues more substantive and do they add value? How does harmonization between the bilateral donor and NGOs impact other coordination efforts in the field? And ultimately, are these reforms serving the final purpose of the proclaimed goal of strengthening civil society? So far no answers have been provided to these questions, which points to the need of further research.

\section{REFERENCES}

ACHARYA, A., DE LIMA, A. T. F. \& MOORE, M. 2006. Proliferation and fragmentation: Transactions costs and the value of aid. The Journal of Development Studies, 42, 1-21.

AFFAIRS, D. M. O. F. 2008a. Koenders: moderniseer en word effectiever door samenwerking en maatwerk [Online]. Available: http://www.rijksoverheid.nl/documenten-enpublicaties/toespraken/2010/02/10/koenders-moderniseer-en-word-effectiever-doorsamenwerking-en-maatwerk.html.

AFFAIRS, N. M. O. F. 2004. Fighting poverty together: a comprehensive development policy. Available: http://www.regjeringen.no/pages/806465/Title_-_contents.pdf.

AID, I. 2006a. Multi Annual Programme Scheme II (MAPS II): Guidelines for NGOs.

AID, I. 2006b. Micro-projects scheme: explanatory notes for grant application.

AID, I. 2008. Civil Society Policy. Available:

http://www.irishaid.ie/media/irishaid/allwebsitemedia/20newsandpublications/publicationpdfseng lish/civil-society-policy.pdf.

AL, V. E. 2008. Evaluation: Finnish Partnership Agreement Scheme. Available:

http://formin.finland.fi/public/default.aspx?contentid=133140\&contentlan=2\&culture=en-US.

COMMITTEE, O. D. A. 2005. Paris Declaration on Aid Effectiveness.

CORNWALL, A. \& GAVENTA, J. 2000. From Users and Choosers to Makers and Shapers Repositioning Participation in Social Policy1. IDS Bulletin, 31, 50-62.

DANIDA. 2006. Administrative guidelines for Danish framework organisations operating under framework agreements with the Ministry of Foreign Affairs.

DANIDA 2006. Guidelines for the administration of the grant scheme for small projects allocated by the Danish Ministry of Foreign Affairs 
DANIDA. 2008. The Civil Society Strategy: Strategy for Danish support to civil society in developing countries. Available:

http://amg.um.dk/en/ /media/amg/Documents/Policies\%20and\%20Strategies/Freedom\%20Demo cracy\%20and\%20Human\%20Rights/Civil\%20Society/samfundsstrategien_uk.ashx.

DANIDA 2010. General Guidelines for Grant Administration through Danish Civil Society Organisations.

DENMARK, M. O. F. A. O. 2011. General Principles governing support to development activities implemented by Danish Civil Society Organisations.

DFID 2006. Civil Society and Development: How DFID Works in Partnership with Civil Society to Deliver the Millennium Development Goals.

DFID. 2007. Governance and Transparency Fund (GTF) [Online]. Available:

http://webarchive.nationalarchives.gov.uk/+/http:/www.dfid.gov.uk/working-with-dfid/fundingschemes/closed-funds/governance-and-transparency-fund-gtf-/.

DFID. 2009. Eliminating World Poverty: Building Our Common Future. Available:

http://consultation.dfid.gov.uk/whitepaper2009/files/2009/03/white-

paper_building_our_common_future_hi-res.pdf.

DJANKOV, S., MONTALVO, J. G. \& REYNAL-QUEROL, M. 2009. Aid with multiple personalities. Journal of Comparative Economics, 37, 217-229.

DOLLAR, D. R. 1998. Assessing aid: What works, what doesn't, and why, Oxford University Press.

EASTERLY, W. 2007. Are aid agencies improving? Economic Policy, 22, 633-678.

EASTERLY, W. \& PFUTZE, T. 2008. Where does the money go? Best and worst practices in foreign aid. The Journal of Economic Perspectives, 22, 29-52.

EFFECTIVENESS, O. F. F. C. D. 2011. The Siem Reap CSO Consensus on the International Framework for CSO Development Effectiveness.

FINLAND, M. F. F. A. O. 2010. Guidelines for Civil Society in Development Policy Available:

http://formin.finland.fi/public/default.aspx?contentid=206482\&contentlan=2\&culture=en-US.

FORUM, 0. 2010b. Istanbul CSO Development Effectiveness Principles

FOWLER, A. 2000. Civil society, NGDOs and social development: changing the rules of the game.

FOWLER, A. 2011. Development NGOs. In: EDWARDS, M. (ed.) The oxford handbook of civil society. Oxford University Press.

FROT, E. \& SANTISO, J. 2010. Crushed aid: fragmentation in sectoral aid, OECD Development Centre.

FROT, E. \& SANTISO, J. 2011. Herding in aid allocation. Kyklos, 64, 54-74.

GIFFIN, J. \& JUDGE, R. 2010. Civil Society Policy and Practice in Donor Agencies. Governance and Social Development Resource Centre. 
HEDMAN, J. A. M. D., IDA. 2011. How DAC members work with Civil Society Organisations: an overview [Online]. Available:

http://www.oecd.org/dac/howdacmembersworkwithcivilsocietyorganisationsanoverview2011.htm.

KARLSTEDT, C. 2010. Mapping of Donors' Conditions and Requirements for CSO Funding. Available: http://www.ituc-csi.org/IMG/pdf/Final_report_100523_Mapping_of_Donor_Conditions.pdf.

KNACK, S. \& RAHMAN, A. 2007. Donor fragmentation and bureaucratic quality in aid recipients. Journal of Development Economics, 83, 176-197.

KOCH, D. \& LOMAN, B. 2009. Unraveling Unrealistic Expectations: The Geographic Choices of Dutch NGOs.

KOCH, D.-J. 2007. Blind spots on the map of aid allocations: Concentration and complementarity of international NGO aid, Research Paper, UNU-WIDER, United Nations University (UNU).

KOCH, D.-J. 2008. A Paris declaration for NGOs? Financing development 2008: Whose ownership? : OECD.

KOCH, D.-J., DREHER, A., NUNNENKAMP, P. \& THIELE, R. 2009. Keeping a low profile: what determines the allocation of aid by non-governmental organizations? World development, 37, 902-918.

MINISTRY FOR FOREIGN AFFAIRS, S. 2009. Pluralism, Policy for support to civil society in developing countries within Swedish Development Cooperation. Available: http://www.government.se/content/1/c6/13/13/60/8c589318.pdf.

MINISTRY FOR FOREIGN AFFAIRS, S. 2012. Finland's Development Policy Programme.

MINISTRY OF FOREIGN AFFAIRS, N. 2009. Policy Memorandum of the Netherlands on Civil Society Organisations Co-operation, Customisation and Added Value.

NEDERLANDEN, K. D. 2012. Staatscourant no. 11736.

NORAD. 2009. Principles for Norad's Support to Civil Society in the South. Available: http://www.norad.no/en/tools-and-publications/publications/publication?key=128394 [Accessed May 2009].

NORAD. 2012. Tracking Impact: An exploratory study of the wider effects of Norwegian civil society support to countries in the South. Available: http://www.norad.no/en/tools-andpublications/publications/publication?key=389645.

NUNNENKAMP, P., WEINGARTH, J. \& WEISSER, J. 2009. Is NGO aid not so different after all? Comparing the allocation of Swiss aid by private and official donors. European Journal of Political Economy, 25, 422-438.

ODELL, J. S. 2001. Case study methods in international political economy. International Studies Perspectives, 2, 161-176.

OECD. 2003. Denmark: DAC peer review 2003.

OECD 2007. Finland DAC Peer Review 2007.

OECD. 2011. Denmark: DAC peer review 2011. Available: http://www.oecd.org/development/peerreviews/47866608.pdf. 
OECD. 2012. Finland DAC Peer Review 2012. Available: http://www.oecd.org/dac/peerreviews/PRFINLAND2012.pdf.

PRATT, B., ADAMS, J. \& WARREN, H. 2009. Official agency funding of NGOs in seven countries: mechanisms, trends and implications, International NGO Training and Research Centre (INTRAC).

RANDELL, J. \& GERMAN, T. 1999c. Denmark. In: SMILLIE, I. \& HELMICH, H. (eds.) Stakeholders: government-NGO partnerships for international development. London: Earthscan Publications Ltd.

RANDELL, J. A. T. G. 1999d. Sweden. In: HELMICH, I. S. A. H. (ed.) Stakeholders: government-NGO partnerships for international development. London: Earthscan Publications Ltd.

RANDELL, J. A. T. G. \& 1999a. Norway. In: HELMICH, I. S. A. H. (ed.) Stakeholders: government-NGO partnerships for international development. London: Earthscan Publications Ltd.

RENARD, R. \& NIJS, L. 2009. Reforming government funding of development NGOs. A comparative analysis of eight European donors. Universiteit Antwerpen, Institute of Development Policy and Management (IOB).

RIDDELL, R. C. 2007. Does foreign aid really work?, Oxford University Press.

RIDDELL, R. C., BEBBINGTON, A. \& PECK, L. 1995. Promoting development by proxy. An evaluation of the development impact of government support to Swedish NGOs, Sida.

RUBEN, R. \& SCHULPEN, L. 2009. How to Allocate Public Funding to Nongovernmental Development Organizations A Critical Assessment of the Dutch Co-Financing System. Nonprofit and voluntary sector quarterly, 38, 287-306.

SCANTEAM 2007. Support Models for CSOs at Country Level - Synthesis Report. Norad report: Discussion $1 / 2008$.

SIDA. 2007. Guidelines for Grants from the appropriation for NGO. Available:

http://www.sida.se/Publications/Import/pdf/sv/Guidelines-for-Grants-from-the-Appropriation-forNon-Governmental-Organisations_1679.pdf.

SIDA. 2007. Sida's support to civil society in development cooperation. Available:

http://www.sida.se/Publications/Import/pdf/sv/Sidas-support-to-civil-society_1672.pdf.

SIDA. 2009. Framework organisations [Online]. Available: http://www.sida.se/English/Partners/CivilSociety-/Funding-support-to-civil-society-organisations--/Framework-organizations-/.

TOJE, A. 2011. Government Funded Non Governmental Organisations - Civil society aid organisations and Donor Governments, the case of Norway. Available: http://asletoje.com/pdf_gallery/102.pdf.

TVEDT, T. 2007. International development aid and its impact on a donor country: a case study of Norway. The European Journal of Development Research, 19, 614-635.

UDSHOLT, L. 2008. Issues paper on Donor strategies for support of civil society and related administrative modalities. Capacitate a/s, Copenhagen.

WORTHINGTON, S. A. \& PIPA, T. 2010. International NGOs and foundations: essential partners in creating an effective architecture for aid. Brookings Blum Roundtable Policy Briefs, 28-36. 
